\title{
Linking human well-being and jellyfish: ecosystem services, impacts, and societal responses
}

\author{
William M Graham $^{1 *}$, Stefan Gelcich ${ }^{2}$, Kelly L Robinson ${ }^{1}$, Carlos M Duarte ${ }^{3,4}$, Lucas Brotz ${ }^{5,6}$, Jennifer E Purcell ${ }^{7}$, \\ Laurence P Madin $^{8}$, Hermes Mianzan ${ }^{9}$, Kelly R Sutherland ${ }^{10}$, Shin-ichi Uye ${ }^{11}$, Kylie A Pitt ${ }^{12}$, Cathy H Lucas ${ }^{13}$, \\ Molly B $\phi$ geberg ${ }^{14}$, Richard D Brodeur ${ }^{15}$, and Robert H Condon ${ }^{16}$
}

Jellyfish are usually perceived as harmful to humans and are seen as "pests". This negative perception has hindered knowledge regarding their value in terms of ecosystem services. As humans increasingly modify and interact with coastal ecosystems, it is important to evaluate the benefits and costs of jellyfish, given that jellyfish bloom size, frequency, duration, and extent are apparently increasing in some regions of the world. Here we explore those benefits and costs as categorized by regulating, supporting, cultural, and provisioning ecosystem services. A geographical perspective of human vulnerability to jellyfish over four categories of human well-being (health care, food, energy, and freshwater production) is also discussed in the context of thresholds and trade-offs to enable social adaptation. Whereas beneficial services provided by jellyfish likely scale linearly with biomass (perhaps peaking at a saturation point), non-linear thresholds exist for negative impacts to ecosystem services. We suggest that costly adaptive strategies will outpace the beneficial services if jellyfish populations continue to increase in the future.

Front Ecol Environ 2014; 12(9): 515-523, doi:10.1890/130298

Eenerally considered to be directly or indirectly harmful to human well-being, jellyfish (Panel 1) have been likened to "pests" of the natural world, sharing a similar reputation to that of wasps, cockroaches, and the like (Richardson et al. 2009). But the human perception of jellyfish as "nuisance" species has led to an overall

\section{In a nutshell:}

- Negative perceptions of jellyfish have led to a lack of under standing about their value (positive, neutral, or negative) in terms of ecosystem services

- Positive services include transporting carbon to greater depths, serving as a source of food for humans, enhancing biodiversity, and contributing to medical advances

- Jellyfish can cost fishing and tourism industries millions of dollars and interrupt power and freshwater production

- Societies will cope with, adapt to, and transform in response to the various impacts associated with increasing jellyfish encounters

- Research exploring the consequences of alternative policy options and the development of information systems and mapping tools will be critical for understanding the costs to human well-being if jellyfish populations increase

${ }^{1}$ Department of Marine Science, University of Southern Mississippi, Stennis Space Center, MS * (monty.graham@usm.edu); ${ }^{2}$ Laboratorio Internacional en Cambio Global $\mathbb{E}$ Center of Applied Ecology and Sustainability, Facultad de Ciencias Biologicas, Pontificia Universidad Catolica de Chile, Santiago, Chile; ${ }^{3}$ Department of Global Change Research, Instituto Mediterráneo de Estudios Avanzados IMEDEA, Esporles, Spain; continued on p 523 lack of awareness regarding their value (positive, neutral, or negative) for ecosystem services.

Widespread coastal and open-ocean blooms of jellyfish have led to the hypothesis that such blooms are increasing in frequency and magnitude around the world (Richardson et al. 2009). Despite uncertainties associated with changing jellyfish populations on a global scale (Condon et al. 2012), evidence for such increases regionally is already available (Brotz et al. 2012; Condon et al. 2013). Consequently, there is concern that anthropogenic impacts through fisheries overharvesting, eutrophication of coastal waters and marginal seas, non-native species introductions, and climate change could trigger increased jellyfish blooms in some locations (Purcell et al. 2007).

As human interactions with coastal ecosystems continue to increase, so will exposure to jellyfish blooms; it is therefore important to evaluate the vulnerability of human well-being to jellyfish, and it is prudent also to present a perspective of costs relative to benefits of jellyfish (Figure 1). We explore examples that illustrate jellyfish impacts on ecosystem services and human well-being in terms of scale. Most ecosystem services scale linearly with jellyfish biomass or numbers, with a possibility of reaching a maximum point of saturation (Figure 1a) - a relationship that is characteristic of marine communities and biodiversity (Schwartz et al. 2000; Balvanera et al. 2006; Worm et al. 2006). In some cases, ecosystem services likely scale independently with jellyfish abundance. In contrast, impacts of jellyfish appear to scale non-linearly, with clear thresholds marking the point where 


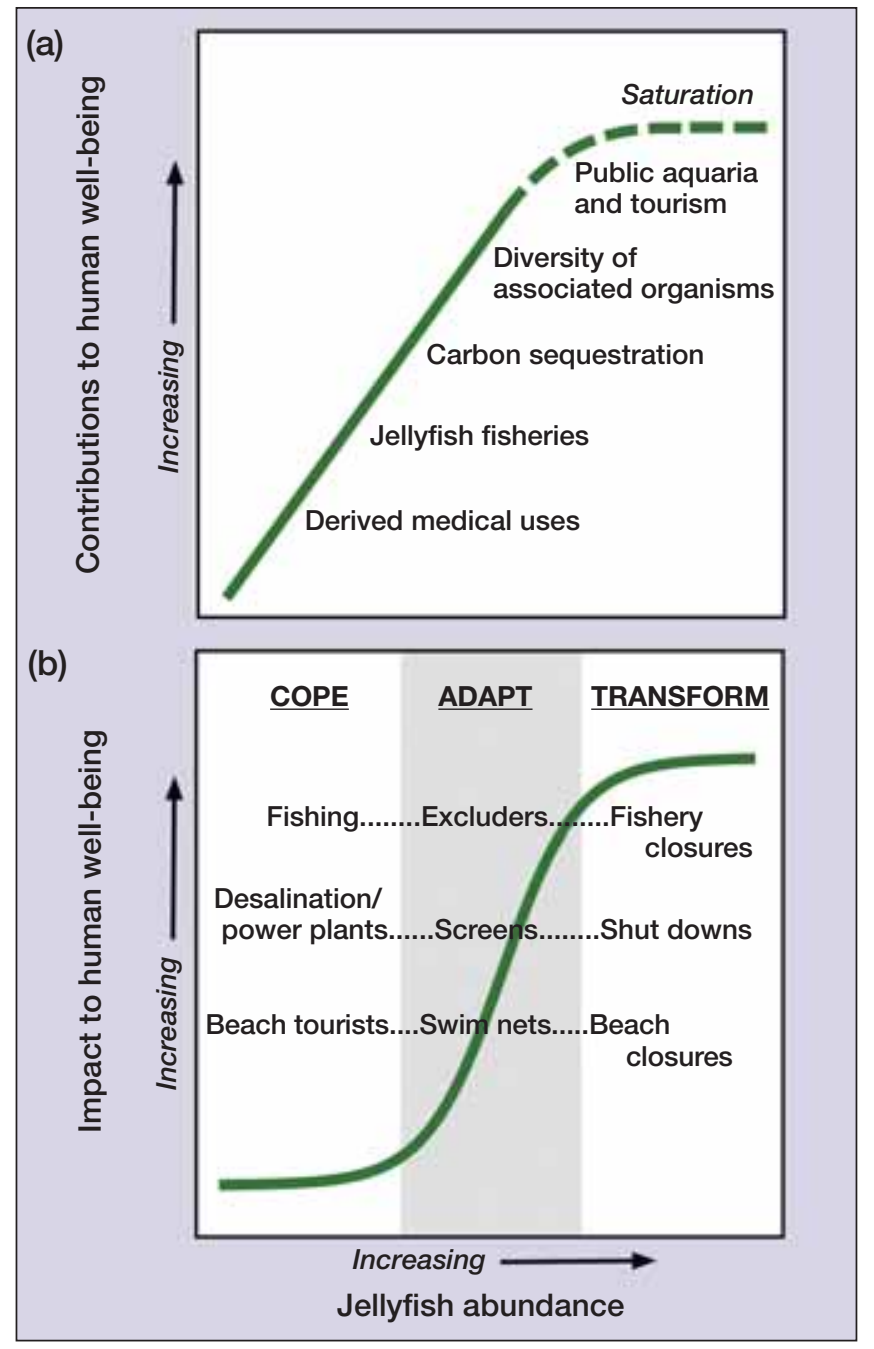

Figure 1. (a) Linear scaling relationship between ecosystem services illustrated in the text and jellyfish abundance. A theoretical saturation (dashed portion) is assumed to occur. (b) Societal responses to increasing jellyfish abundance illustrate thresholds where adaptation capacity will be needed to avoid a societal transformation.

humans must adapt, often using costly technological strategies, or else the affected social systems will be transformed (Figure 1b).

\section{Jellyfish ecosystem services}

Jellyfish provide a variety of ecosystem services as defined by MA (2005), which grouped them into four categories: regulating, supporting, cultural, and provisioning (Table 1; Figure 2). A full exploration of the services provided by jellyfish is discussed elsewhere (see Doyle et al. 2014 for a review).

\section{Regulating services}

Rapid sinking of organic-rich particles to the deep sea is a key process of the biological pump in sequestering carbon from the atmosphere. Salps (pelagic tunicates belonging to the Order Salpida) in particular have high rates of filter-feeding (Harbison and Gilmer 1976), retain a wide range of particle sizes $(<1.0 \mu \mathrm{m}$ to $1 \mathrm{~mm}$; Sutherland et al. 2010), and produce large and rapidly sinking fecal pellets (up to $1000 \mathrm{~m} \mathrm{~d}^{-1}$; Phillips et al. 2009) as compared with phytoplankton-derived particles that sink passively and can take a month or longer to be sequestered in the deep ocean (Sarthou et al. 2005). Because individual small phytoplankton cells typically do not sink rapidly, packing them into salp fecal pellets, as well as the deposition of dead salps, are among the most important vertical transport processes in the sea (Madin et al. 2006; Lebrato et al. 2012; Henschke et al. 2013). The regulating service that salps provide for carbon sequestration is likely to be a direct function of salp abundance in the oceans.

\section{Supporting services}

Jellyfish function as hosts, buoyant substrates, and refugia for various other animals, given that open-ocean ecosystems intrinsically lack physical refugia. Large scyphomedusae and the siphonophore Physalia physalis (commonly known as Portuguese man o' war) often harbor juvenile or small adult fish under their bells or among their tentacles. When associated with jellyfish, these fish - many of which are commercially important (eg gadoid species; see WebTable 1 for references) - may benefit not only from decreased predation but also from improved feeding opportunities on the jellyfish itself and on its prey (Masuda 2009).

Many invertebrates also depend on jellyfish for part of their life-history (Ohtsuka et al. 2009). The most specialized of these are hyperiid amphipods, the juveniles of which rely on a few closely related jellyfish species for substrate, transport, food, and shelter (Gasca and Haddock 2004). Barnacles, copepods, isopods, and some

\section{Panel 1. Jellyfish bodies and jellyfish blooms}

"Jellyfish" is a generic term including free-swimming or floating cnidarians falling in the Classes Scyphozoa, Hydrozoa, and Cubozoa. At times, the term "jellyfish" is used to describe gelatinous plankton of the Phyla Cnidaria, Ctenophora (comb jellies), and Chordata (larvaceans, salps, doliolids, and pyrosomes). Jellyfish occupy all of the world's oceans from surface to bottom, but influence humans mostly along the heavily used shallow coastal margins.

"Jellyfish" converge in several morphological and life-history characteristics although their evolutionary paths diverged hundreds of millions of years ago. High individual growth rates and complex life histories involving asexual reproduction allow for rapid population growth. Such rapid increases in size and number generate sudden "blooms" that remain aggregated for days to weeks due to passive (physical) and active (behavioral) factors. These blooms evolved as part of normal patterns of reproduction. 


\begin{tabular}{|c|c|c|c|c|}
\hline Service category & Affected service & Form of impact & References & Groups \\
\hline Regulating & $\begin{array}{l}\text { Trophic effects and } \\
\text { food web changes }\end{array}$ & $\begin{array}{l}\text { Forcing trophic cascades; } \\
\text { keystone predatory role on lower } \\
\text { trophic level organisms }\end{array}$ & $\begin{array}{l}\text { Feigenbaum and Kelly } \\
\text { (1984); } \\
\text { Pauly et al. (2009) }\end{array}$ & $\begin{array}{l}\text { Medusae and } \\
\text { ctenophores }\end{array}$ \\
\hline Supporting & Biodiversity & $\begin{array}{l}\text { Increased predation by non-endemic } \\
\text { or invasive species reduces } \\
\text { biodiversity of plankton }\end{array}$ & Purcell et al. (200I) & $\begin{array}{l}\text { Medusae and } \\
\text { ctenophores }\end{array}$ \\
\hline \multirow[t]{3}{*}{ Provisioning } & Fisheries & $\begin{array}{l}\text { Direct impacts on fisheries landings and } \\
\text { damage to fishing gear; indirect impacts } \\
\text { on sizes of commercial fish and } \\
\text { invertebrate harvests }\end{array}$ & $\begin{array}{l}\text { Kideys et al. (2005); } \\
\text { Purcell et al. (2007); } \\
\text { Daryanbard and } \\
\text { Dawson (2008); } \\
\text { Kim et al. (20I2); } \\
\text { Quiñones et al. (2013) }\end{array}$ & $\begin{array}{l}\text { Medusae and } \\
\text { ctenophores }\end{array}$ \\
\hline & Aquaculture & $\begin{array}{l}\text { Mortality and illness to fish; increased } \\
\text { cleaning costs }\end{array}$ & $\begin{array}{l}\text { Doyle et al. (2008); } \\
\text { Baxter et al. (20II) }\end{array}$ & $\begin{array}{l}\text { Medusae, } \\
\text { siphonophores, } \\
\text { and ctenophores }\end{array}$ \\
\hline & Fresh water and energy & $\begin{array}{l}\text { Reduced function of desalination and } \\
\text { power plants; increased maintenance } \\
\text { and prevention costs }\end{array}$ & $\begin{array}{l}\text { Daryanbard and Dawson } \\
\text { (2008); see WebTable } 4\end{array}$ & Large medusae \\
\hline \multirow[t]{2}{*}{ Cultural } & Recreational & $\begin{array}{l}\text { Direct impacts on human health care } \\
\text { and warning systems; indirect costs of } \\
\text { tourist satisfaction on coasts }\end{array}$ & $\begin{array}{l}\text { Purcell et al. (2007); } \\
\text { Gershwin et al. (2010) }\end{array}$ & $\begin{array}{l}\text { Medusae (especially } \\
\text { cubozoans) and } \\
\text { siphonophores }\end{array}$ \\
\hline & $\begin{array}{l}\text { Social relations } \\
\text { and politics }\end{array}$ & $\begin{array}{l}\text { Change patterns of social, economic, } \\
\text { and political organization in particular } \\
\text { cultures; combat capabilities }\end{array}$ & $\begin{array}{l}\text { Prusaczyk et al. (1995); } \\
\text { Anonymous (1999); } \\
\text { Mancuso (2006) }\end{array}$ & Medusae \\
\hline
\end{tabular}

larval shrimp and crabs (including those in the deep ocean) also find shelter on jellyfish (Arai 2005; Gasca et al. 2007). In all cases, the jellyfish host provides an ecological niche that supports a variety of species that might not otherwise be able to sustain themselves in the water column. These jellyfish-mediated microhabitats are a factor that sustains oceanic biodiversity. Although the number of known jellyfish-associated species is substantial (WebTable 1), there has been little analysis of associated species diversity and jellyfish abundance. Given that a limited subset of any community may tolerate (or be attracted to) jellyfish as a substrate, it is reasonable to suspect that associated diversity reaches a saturation point at higher jellyfish abundances.

\section{Cultural services}

Jellyfish generate tourist revenue, possess aesthetic value, and facilitate environmental education. The marine lakes of the Pacific Island nation of Palau are home to Mastigias populations; the lack of a notable sting from the jellyfish in these lakes helps draw over 30000 visitors annually to swim with them. Recreational SCUBA diving with the giant jellyfish (Nemopilema nomurai) has become popular in the Sea of Japan, where approximately 10 000-15 000 divers participated in this activity in 2009 (S-I Uye, unpublished).

Jellyfish are also a large source of revenue for public aquaria, with a wide array of species on exhibit throughout the world. There has been a rapid market expansion of jellyfish in aquarium exhibits worldwide since the Monterey Bay Aquarium opened its first large-scale \$3.5million jellyfish exhibit in 2012 (WebTable 2; unless noted otherwise, all monetary values are expressed in US dollars). Exhibits range from dozens of tanks and largescale husbandry operations to single-tank display systems offered for purchase by private enthusiasts. Despite the success of these exhibits, their economic value is not driven by non-captive jellyfish population fluctuations.

\section{Provisioning services}

Human consumption of jellyfish has increased in recent decades, especially in Asia, resulting in the growth of commercial jellyfish fisheries and the development of a multi-million-dollar mariculture industry. Most of these fisheries are sited in Asia but smaller operations have been established elsewhere (eg in the US; FAO 2011). The annual global harvest of jellyfish - estimated at 420918 metric tons in 2011 - exceeds the catch of many traditional fisheries (eg lobster). While the opening or expansion of economic markets has likely resulted in accelerated harvests, the ultimate yield of jellyfish biomass, like that of finfish, is sustainable only by removing jellyfish at or below the natural rate of population replenishment. 


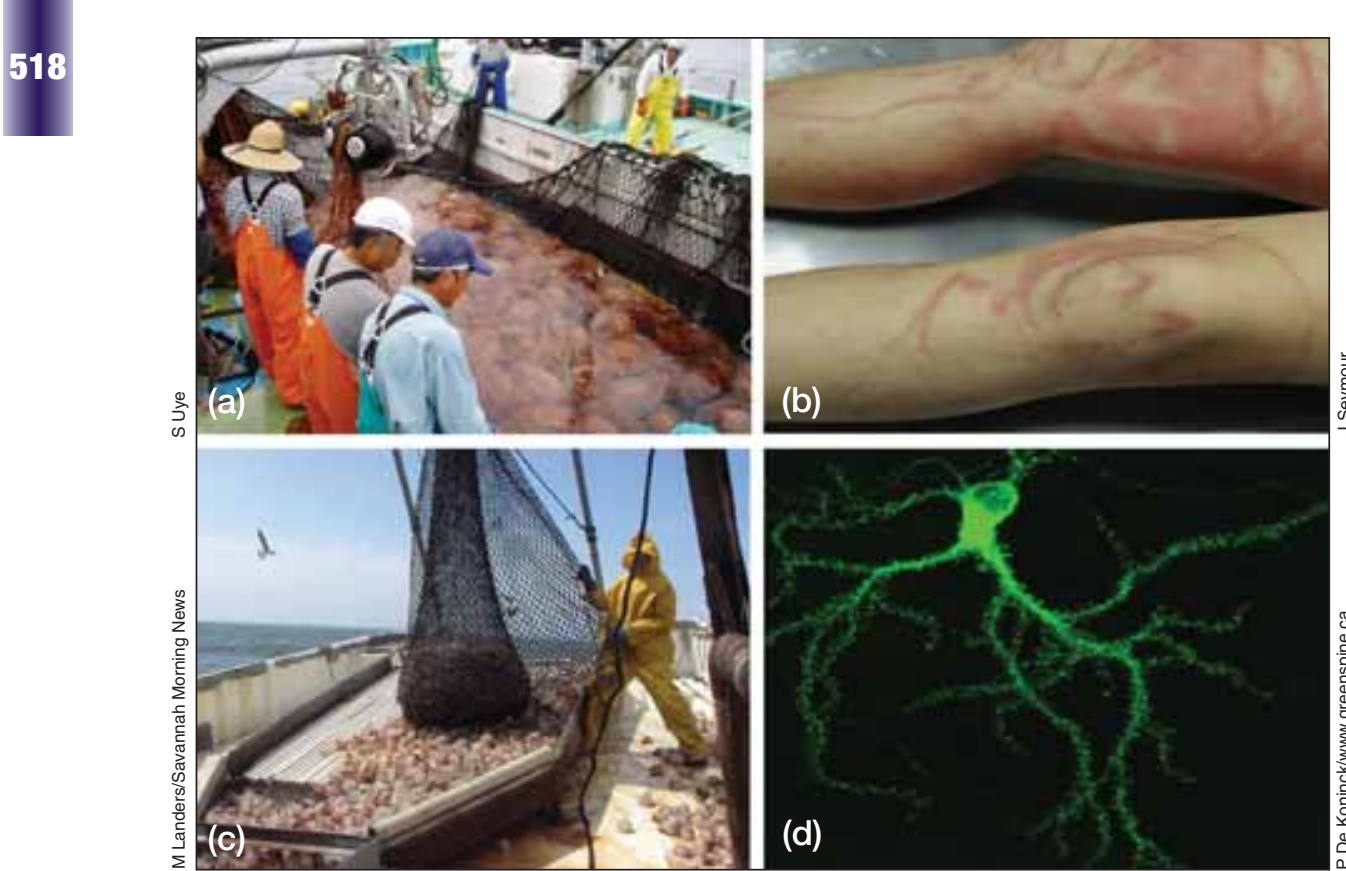

Figure 2. Two adverse impacts and two services of jellyfish: (a) Large blooms of Nomura's jellyfish (Nemopilema nomurai) clog set nets around Japan and South Korea; (b) life-threatening stings by box jellies of northern Australia are a risk that swimmers face every year; (c) Georgia (US) jellyfish fishery exports cannonball jellies to Asian markets; (d) Green Fluorescent Protein, derived from the hydromedusa Aequorea victoria, is widely used in medical diagnoses.

Jellyfish have also contributed to advances in medicine. $P$ physalis provided the basis for understanding anaphylaxis, earning Charles Richet the 1913 Nobel Prize in Medicine. Isolation of the Green Fluorescent Protein from Aequorea victoria provided the molecular biology field with a luminescent marker that is extensively used in cellular research, medical diagnosis, and treatment, and led to the 2008 Nobel Prize in Chemistry. Potential applications of jellyfish toxins as anticancer compounds (eg Chrysaora quinquecirrha; Balamurugan et al. 2010; Leone et al. 2013) and antioxidant nutritional supplements (eg Rhopilema esculentum; Yu et al. 2006) are also being explored. Jellyfish mucin and collagen may have potential disease-modifying effects on osteoarthritis (Addad et al. 2011). Box jellyfish have provided useful models facilitating key advances in understanding the evolution and neurobiology of vision (Nilsson et al. 2005). Some of these medical products will be obtained from natural harvest and subject to the same sustainability rules as jellyfish fisheries; genetic advances will be entirely independent of jellyfish biomass in the sea.

\section{Negative effects on human well-being}

As humans become increasingly dependent on ecosystem services provided by the oceans, the negative impacts of jellyfish on some of those services will likely become more apparent. We present a geographical perspective of human vulnerability to jellyfish over four major categories of human well-being: food production, energy pro- duction, freshwater production, and human health (Figure 3; Table 1).

\section{Fisheries and aquaculture}

Twenty of the 27 largest marine capture fisheries, as measured by landings, are pelagic fish harvested by nets (trawls, seines, and fixed nets; FAO 2011). These fisheries represent 26.7 million metric tons, or one-third of the world's marine capture fisheries. Largely distributed around major centers of coastal productivity (upwelling areas and large rivers), the high biological productivity that drives these fisheries also drives jellyfish biomass (Figure 3a). Gear fouling and aquaculture fish mortality due to jellyfish have been reported in all the world's major fishing areas (Purcell et al. 2007), and have resulted in injuries to fishers, destruction of nets, loss of harvest, increased fishing and maintenance efforts, lowered quality of harvest, and fishery closures (Table 1).

During the past 10 years, blooms of $\mathrm{N}$ nomurai and Aurelia spp around Japan and the Korean Peninsula, and within the East China Sea, have been particularly detrimental for local fishing communities. Estimated losses associated with a $2005 \mathrm{~N}$ nomurai bloom in Japanese waters were equivalent to $\$ 300$ million (Uye 2011). Blooms also occurred in 2006, 2007, and 2009. Annual direct damages to South Korean fisheries from jellyfish during 2006-2010 were estimated to be between $\$ 68.2$ million and \$205 million (Kim et al. 2012). Jellyfish were also reported to have caused $\$ 10$ million in losses to the Gulf of Mexico shrimp fishery in 2001 (Graham et al. 2003) and more than $\$ 200000$ to the Peruvian anchoveta fishery (Quiñones et al. 2013).

There is a nearly complete overlap between documented jellyfish blooms and the 20 largest net fisheries as of 2010 (Figure 3a). In addition to direct effects on fisheries catches, the indirect effects include intraguild competition, egg and larval predation, and redirected energy flows in food webs from co-occurring jellyfish blooms (WebPanel 1). This overlap represents a substantial risk to a major portion (35\%) of the world's ocean-harvested protein resources (Figure 3a; WebPanel 2).

\section{Ingress}

Jellyfish have caused some of the most commonly reported ingress problems at coastal desalination plants, as well as at nuclear and coal-fired power facilities. With $44 \%$ of the world's human population living within 100 $\mathrm{km}$ of the coast, energy demands are largely met by power 
plants equipped with seawater-cooled condensers. Many of the world's energy production sites overlap in space and time with recurring blooms of jellyfish, and jellyfish ingress at such facilities occasionally leads to reductions or complete loss of power (Purcell et al. 2007). An incident at the Sual Power Plant resulted in widespread power outages in the Philippines in 1999 (Anonymous 1999). Jellyfish caused nuclear power plants to shut down temporarily in Israel, Scotland, and Japan in 2011 and, more recently, in the US and Sweden (WebTable 4). Blooms of Aurelia spp have also forced a sustained reduction in power output around the Inland Sea of Japan.

Jellyfish ingress has consequences not only for power plant operations but also for fish inhabiting adjacent waterways. The 2011 ingress of Aurelia spp into the Port St Lucie, Florida, nuclear power plant resulted in the mortality - via gill damage and suffocation - of at least 100 Critically Endangered goliath grouper (Epinephelus itajara) that had congregated in the facility's warm-water effluent (Anderson 2011). The ultimate impact of this loss to the reproductive stock has not yet been realized; however, the estimated $8165 \mathrm{~kg}$ of grouper killed approximates the entire landings of the species for eastern Florida in the year preceding establishment of a catch moratorium.

Freshwater availability has been identified as the most critical issue for human health, industrial development, and national security worldwide (Vörösmarty et al. 2010). Advances in seawater desalination technologies have allowed population expansion in many of the world's underdeveloped arid environments. Because the global distribution of desalination plants is concentrated in environments characterized by low biological productivity, the incidence of jellyfish ingress has been low; however, notable events include one in urban Muscat, Oman, where the freshwater supply was reduced by $50 \%$ for several days when jellyfish clogged plant intakes (Figure 3a; Vaidya 2003).

\section{Tourism}

The negative effects of jellyfish on coastal tourism (beach closures and stings) are well-known, particularly to people who visit the warm waters along the northern Mediterranean, north Queensland (Australia), and
Florida coasts. Tourism is the largest cultural economic driver in these regions, accounting for $\$ 67$ billion, $\$ 20$ billion, and $\$ 57$ billion in annual revenue, or $11 \%, 7.4 \%$, and $7.6 \%$ of the gross domestic product in 2010 for Spain, Queensland, and Florida, respectively. Jellyfish regularly generate concern for beachgoers, given that their presence can cause mass injuries or death (Figures $2 \mathrm{~b}$ and $3 \mathrm{~b}$ ).

The majority of human fatalities due to stings have occurred in the tropical belt bounded by the $25^{\circ} \mathrm{C}$ surface isotherm (Figure 3b). Some of the most extreme examples are from northern Australia where the cubozoan "box jellyfish" Chironex fleckeri has been responsible for approximately 70 fatalities and hundreds of injuries (Currie and Jacups 2005). In addition to C fleckeri, several smaller cubozoans cause Irukandji syndrome, the symptoms of which include difficulty breathing, hypertension, nausea, and abdominal cramps. However, fatalities from Irukandji jellyfish are rare $(<1 \%$ of stings; Gershwin et al. 2010). As climate change drives poleward 


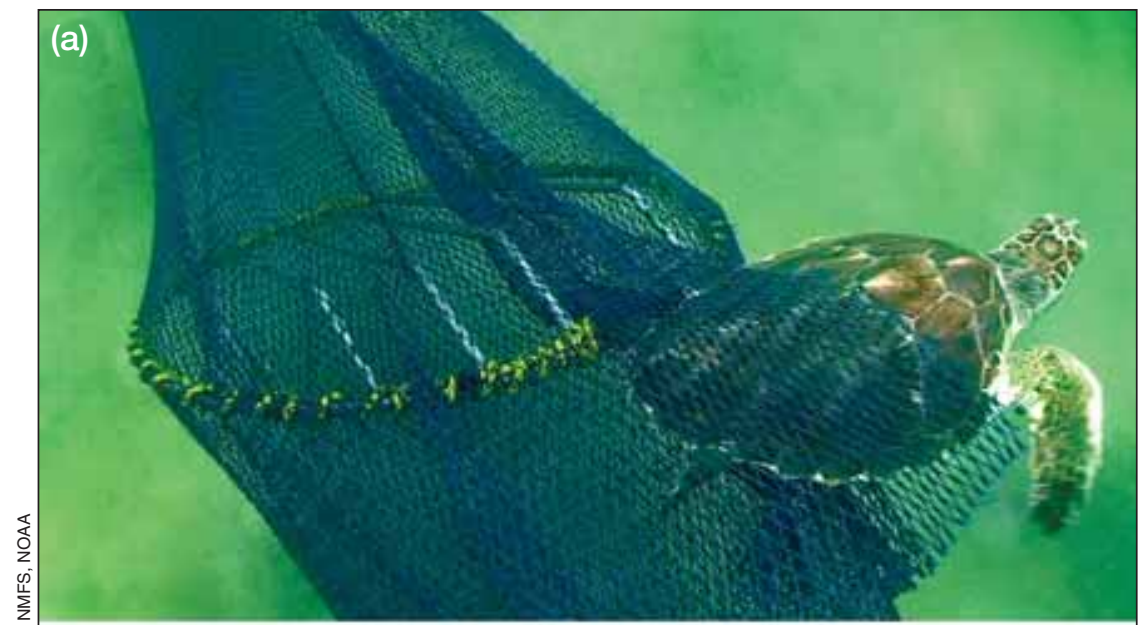

long-lasting, as these incidents are often magnified by the news media, leading to negative public perception of the beaches where they occurred.

\section{Risks, thresholds, and societal responses}

Anthropogenic pressures on the world's oceans and resources have contributed to declining ocean health (Halpern et al. 2012). Various scientific publications have illustrated notable jellyfish blooms as possible indicators of human-driven, degraded ocean ecosystems (Hay 2006;

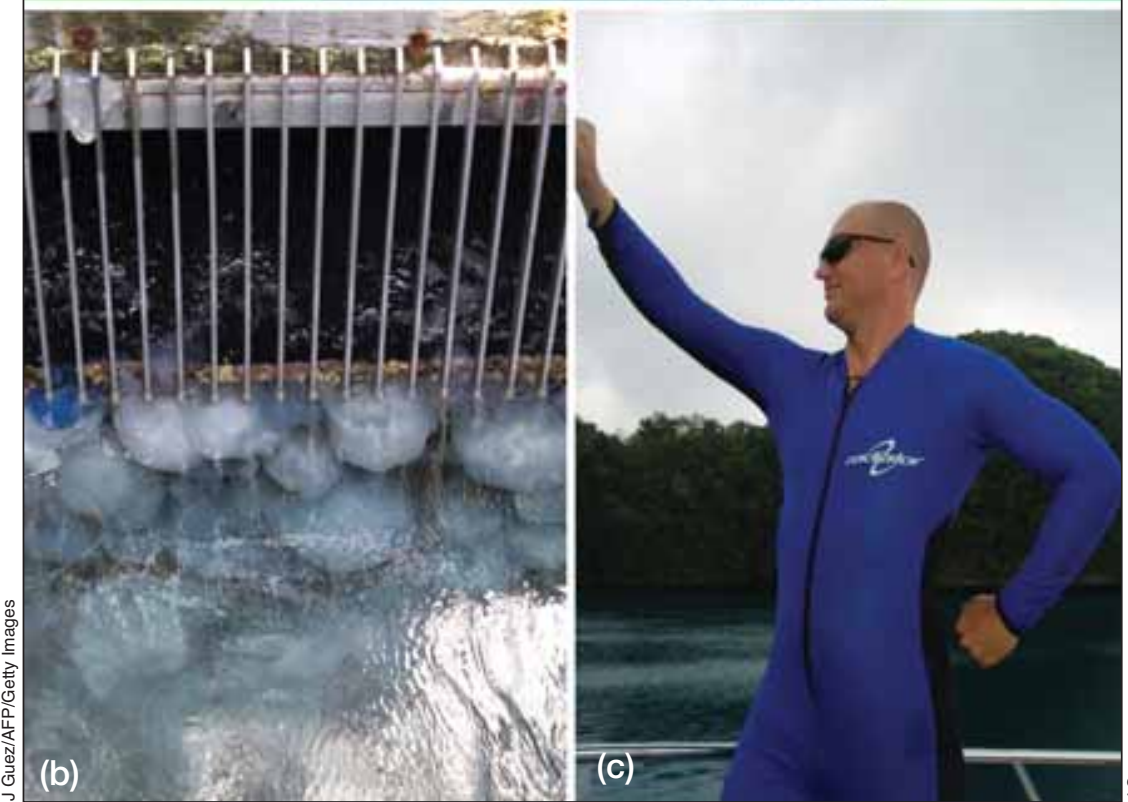

Figure 4. Adapting strategies for jellyfish blooms. (a) Sea turtle excluder devices originally designed by Gulf of Mexico shrimpers as "jelly shooters" for removing jellyfish from trawl nets; (b) barrier screening for removing jellyfish and other debris at a power plant cooling water intake; (c) stinger suits widely utilized across northern Australia as a primary defense against box jellyfish.

expansion of tropical waters and plankton communities (eg Hinder et al. 2014), future incidence of such stings is likely to rise.

There are both direct and indirect costs associated with cubozoan stings in northern Australia. Aerial medical evacuations in the late 1990s were estimated to cost \$AU65 000 to \$AU1.9 million annually (Fenner 1999). Indirect losses related to tourists avoiding sting-prone areas are difficult to calculate but are expected to be higher than direct costs. Lost revenue following several hundred stings and two fatalities from Irukandji jellyfish near Cairns, north Queensland, in 2002 was valued at $\$ 49$ million (Gershwin et al. 2010).

The possibility of jellyfish-associated human injury or death - real or perceived - is particularly high in regions where highly venomous cubozoans are found. Although jellyfish blooms may be transient, their impact can be although responses may reach saturation point at very high concentrations (Figure 1a; WebFigure 1). Alternatively, the impacts of jellyfish blooms may be complex and nonlinear, and can be described by thresholds. In a threshold response (Figure 1b), there are three elements to consider: (1) a region of minimal change at low jellyfish densities reflects "coping"; (2) a region of rapid change - representing the threshold - indicates "adaptation" costs to counteract impacts; and (3) a highdensity saturation region where little additional impact occurs with increasing jellyfish abundance and where "transformational" change will be necessary to maintain human well-being.

Increased vulnerability of human well-being to rising jellyfish abundance and associated impacts should arguably trigger adaptation (as opposed to coping or transformational) strategies. The relative scaling of ser- 
vices and impacts suggests that more jellyfish result in disproportionately higher impacts as compared with services potentially provided. This is an important consideration because a long-term shift toward more jellyfish may, in some cases, serve as a metric for degraded ecosystem health. In the fisheries of Japan and South Korea, discussed above, social feedbacks have been triggered by the elevated costs of fishing that resulted from jellyfishrelated impacts. Once the profitability margin of the catch was reduced, adaptation strategies by local fishing councils emerged. Similar adaptive behavior has also arisen in response to jellyfish ingress at power plants (Figure 4b; WebPanel 3).

The scaling of density-dependent impacts of jellyfish on commercial fisheries described in previous sections is nonlinear or perhaps saturating at very high concentrations. Fishers would generally cope at low densities (eg by repairing nets), adapt at moderate densities (eg using jellyfish exclusion devices and steel wire slicers in trawls; Figure 4a), and transform at high densities (eg strategically retreating from traditional fishing grounds and changing livelihoods; Okino et al. 2009). Thus, an impact threshold is reached where gear fouling becomes increasingly problematic. Gear type and handling time will determine the shape of the curve at low to moderate concentrations, but multiple economic factors (harvest value, fuel and labor, and gear replacement costs) will determine threshold levels for which adaptation or transformational governance strategies will be necessary.

Factors related to public perception influence the nonlinear relationship between tourist activity and jellyfish presence or abundance in addition to the direct costs of stings. Even the occasional sting reported in northern Australia has a marked impact on vacationers' perceptions, because of the potentially fatal consequences. Thus, the tourism industry has accepted an extremely low threshold for coping with jellyfish and has adapted to minimize risks, including implementing education programs, monitoring cubozoan densities daily, posting warning signs, establishing netted enclosures, developing lycra "stinger suits" (Figure 4c), offering publically accessible first-aid supplies, and instituting beach closures (Gershwin et al. 2010).

An interesting comparison of the social response to potential jellyfish sting events can be drawn from recent (2011-2012) incidents in the Mediterranean and Florida where the nonlethal mauve stinger (Pelagia noctiluca) bloomed in extraordinary numbers. Mediterranean resort operators have adopted a lower threshold because competition among destinations is intense. Although shortterm encounters may have minimal impact (eg if a coastal beach is temporarily closed, tourists visit a swimming pool instead), the persistent presence of jellyfish throughout the season could cause tourists to seek alternative destinations. Operators have consequently adapted, using countermeasures such as exclusion barriers and physical removal. In contrast, vacationers in Florida almost expect an occasional sting; operators there cope with, rather than adapt to, the presence of jellyfish. In Florida, loss of tourism revenue would likely far outweigh any perceived benefits gained from adaptation, since the countermeasures or education would only reinforce a negative connotation of Florida beaches and drive tourists to other coastal destinations.

\section{Conclusion}

Assessing the consequences of jellyfish population increases for human well-being requires an understanding of how a society is likely to respond to different degrees of impact or to the perception of impacts. Socioeconomic systems will react through coping, adaptation, or transformation strategies, with increasing costs associated with changes. These may be spontaneous responses or may be deliberate, adaptive strategies. Evidence presented here indicates that, of those reviewed, societies are probably moving from "coping" to "adaptation" strategies. To maintain adaptive strategies and avoid the costs of transformation (Figure 1b), we argue that social learning must be increased. This approach includes the use of scenarios and simulations to explore the consequences of alternative policy options and the development of information systems and mapping tools that contribute to building trust among decision makers and stakeholders.

Changes in jellyfish abundance over timescales that are likely to be important to human well-being (seasons to decades) are highly variable and depend on the human frame of reference to assess whether a long-term increase is occurring (Condon et al. 2012). For the purpose of understanding thresholds and adaptations, long-term increases may, in fact, be less important than the large fluctuations that occur between years and over climaterelated cycles (Brodeur et al. 2008; Robinson and Graham 2013). We show that while jellyfish provide important ecosystem services, the value of their services to society likely increases at a rate lower than the value of costs associated with increased jellyfish abundance. However, our model - which, under a scenario of increasing jellyfish abundance, involves faster growth of impacts than services - requires validation with improved data. Moreover, the specific threshold at which losses exceed benefits needs to be empirically assessed as critical elements to inform policy and management responses.

As a starting point, we recommend comprehensive analyses to identify jellyfish-related stressors (eg fisheries overharvesting, eutrophication, species introductions, climate change; reviewed by Purcell et al. 2007) most likely to negatively affect human well-being. Such investigations are more important to societies that are particularly vulnerable (Figure 3), especially developing nations, where net-based fisheries provide both income and food (Tacon and Metian 2009). If long-term increases in jellyfish are observed, then it will be critical to reduce the susceptibility of these socioeconomic systems to expected 
changes by guiding transformation processes towards desirable trajectories (Gelcich et al. 2010). Research addressing jellyfish-related impacts on ecosystem services and the economic value of those services is an important challenge to improving long-term human well-being - an issue that resonates with both the public and with policy makers.

\section{Acknowledgements}

Funding for the National Center for Ecological Analysis and Synthesis comes from National Science Foundation Grant DEB-94-21535, the University of California at Santa Barbara, and the State of California. We thank S Piraino for suggested references.

\section{References}

Addad S, Exposito J-Y, Faye C, et al. 2011. Isolation, characterization and biological evaluation of jellyfish collagen for use in biomedical applications. Mar Drugs 9: 967-83.

Anderson RL. 2011. Unit 1 manual reactor trip due to high condenser backpressure caused by severe influx of jellyfish into the intake structure. Washington, DC: US Nuclear Regulatory Commission. Licensee Event Report 2011-001, Docket No 50-335.

Anonymous. 1999. The Philippines: dark days for Estrada. The Economist. 16 Dec

Arai MN. 2005. Predation on pelagic coelenterates: a review. J Mar Biol Assoc UK 85: 523-36.

Balamurugan E, Reddy BV, and Menon VP. 2010. Antitumor and antioxidant role of Chrysaora quinquecirrha (sea nettle) nematocyst venom peptide against Ehrlich ascites carcinoma in Swiss albino mice. Mol Cell Biochem 338: 69-76.

Balvanera P, Pfisterer AB, Buchmann N, et al. 2006. Quantifying the evidence for biodiversity effects on ecosystem functioning and services. Ecol Lett 9: 1146-56.

Bastian T, Stokes D, Kelleher JE, et al. 2011. Fisheries bycatch data provide insights into the distribution of the mauve stinger (Pelagia noctiluca) around Ireland. ICES J Mar Sci 68: 436-43.

Baxter EJ, Sturt MM, Ruane N, et al. 2011. Gill damage to Atlantic salmon (Salmo salar) caused by the common jellyfish (Aurelia aurita) under experimental challenge. PLoS ONE 6: e18529.

Brodeur RD, Decker MB, Ciannelli L, et al. 2008. Rise and fall of jellyfish in the eastern Bering Sea in relation to climate regime shifts. Prog Oceanogr 77: 103-11.

Brotz L, Cheung WWL, Kleisner K, et al. 2012. Increasing jellyfish populations: trends in large marine ecosystems. Hydrobiologia 690: $3-20$.

Condon RH, Graham WM, Duarte CM, et al. 2012. Questioning the rise of gelatinous zooplankton in the world's oceans. BioScience 62: 160-69.

Condon RH, Duarte CM, Pitt KA, et al. 2013. Recurrent jellyfish blooms are a consequence of global oscillation. P Natl Acad Sci USA 110: 1000-05.

Currie BJ and Jacups SP. 2005. Prospective study of Chironex fleckeri and other box jellyfish stings in the "Top End" of Australia's Northern Territory. Med J Australia 183: 631-36.

Daryanbard R and Dawson MN. 2008. Jellyfish blooms: Crambionella orsini (Scyphozoa: Rhizostomeae) in the Gulf of Oman, Iran, 2002-2003. J Mar Biol Assoc UK 88: 477-83.

Doyle TK, De Haas H, Cotton D, et al. 2008. Widespread occurrence of the jellyfish Pelagia noctiluca in Irish coastal and shelf waters. J Plankton Res 30: 963-68.

Doyle TK, Hays GC, Harrod C, and Houghton JDR. 2014. Ecological and societal benefits of jellyfish. In: Pitt KA and
Lucas CH (Eds). Jellyfish blooms. Dordrecht, the Netherlands: Springer.

FAO (Food and Agriculture Organization of the United Nations, Fisheries and Aquaculture Department). 2011. Statistics and information service. FishStat J: universal software for fishery statistical time series.

Feigenbaum D and Kelly M. 1984. Changes in the lower Chesapeake Bay food chain in presence of the sea nettle Chrysaora quinquecirrha (Scyphomedusa). Mar Ecol-Prog Ser 19: 39-47.

Fenner PJ. 1999. Irukandji envenomation in far north Queensland. Med J Australia 170: 512.

Gasca R and Haddock SHD. 2004. Associations between gelatinous zooplankton and hyperiid amphipods (Crustacea: Peracarida) in the Gulf of California. Hydrobiologia 530/531: 529-35.

Gasca R, Suarez-Morales E, and Haddock SD. 2007. Symbiotic associations between crustaceans and gelatinous zooplankton in deep and surface waters off California. Mar Biol 151: 233-42.

Gelcich S, Hughes TP, Olsson P, et al. 2010. Navigating transformations in governance of Chilean marine coastal resources. $P$ Natl Acad Sci USA 107: 16794-99.

Gershwin L-A, Nardib M, Winkelc KD, and Fenner PJ. 2010. Marine stingers: review of an under-recognized global coastal management issue. Coast Manage 38: 22-41.

Graham WM, Martin DL, Felder DL, et al. 2003. Ecological and economic implications of a tropical jellyfish invader in the Gulf of Mexico. Biol Invasions 5: 53-69.

Halpern BS, Longo C, Hardy D, et al. 2012. An index to assess the health and benefits of the global ocean. Nature 488: 615-22.

Harbison GR and Gilmer RW. 1976. The feeding rates of the pelagic tunicate Pegea confoederata and two other salps. Limnol Oceanogr 21: 517-28.

Hay SJ. 2006. Marine ecology: gelatinous bells may ring change in marine ecosystems. Curr Biol 16: 679-82.

Henschke N, Bowden DA, Everett JD, et al. 2013. Salp-falls in the Tasman Sea: a major food input to deep-sea benthos. Mar EcolProg Ser 491: 165-75.

Hinder SL, Gravenor MB, Edwards M, et al. 2014. Multi-decadal range changes vs thermal adaptation for north east Atlantic oceanic copepods in the face of climate change. Glob Change Biol 20: 140-46.

Kideys AE, Roohi A, Bagheri S, et al. 2005. Impacts of invasive ctenophores on the fisheries of the Black Sea and Caspian Sea. Oceanography 18: 76-85.

Kim D-H, Seo JN, Yoon YD, and Suh Y-S. 2012. Estimating the economic damage caused by jellyfish to fisheries in Korea. Fisheries Sci 78: 1147-52.

Lebrato M, Pitt KA, Sweetman AK, et al. 2012. Jelly-falls historic and recent observations: a review to drive future research directions. Hydrobiologia 690: 227-45.

Leone A, Lecci RM, Durante M, and Piraino S. 2013. Extract from the zooxanthellate jellyfish Cotylorhiza tuberculata modulates gap junction intercellular communication in human cell cultures. Mar Drugs 11: 1728-62.

MA (Millennium Ecosystem Assessment). 2005. Ecosystem and human well-being: a framework for assessment. Washington, DC: Island Press.

Madin LP, Kremer P, Wiebe PH, et al. 2006. Periodic swarms of the salp Salpa aspera in the slope water off the NE United States: biovolume, vertical migration, grazing, and vertical flux. DeepSea Res 53: 804-19.

Mancuso R. 2006. Mighty warship feels the sting (Australian jellyfish attack USS Ronald Reagan!). News.au.com (via Free Republic.com). www.freerepublic.com/focus/f-news/1566004/ posts. Viewed 9 Oct 2013

Masuda R. 2009. Ontogenetic changes in the ecological function of the association behavior between jack mackerel Trachurus 
japonicus and jellyfish. Hydrobiologia 616: 269-77.

Nilsson D-E, Gislén L, Coates MM, et al. 2005. Advanced optics in a jellyfish eye. Nature 435: 201-05.

Ohtsuka S, Koike K, Lindsay D, et al. 2009. Symbionts of marine medusae and ctenophores. Plank Benthos Res 4: 1-13.

Okino A, Murayama T, and Inoye Y. 2009. Development of fishing gear to exclude and release giant jellyfishes from an offshore trawl net. Nippon Suisan Gakk 75: 6-18.

Pauly D, Graham W, Libralato S, et al. 2009. Jellyfish in ecosystems, online databases, and ecosystem models. Hydrobiologia 617: 67-85.

Phillips B, Kremer P, and Madin LP. 2009. Defecation by Salpa thompsoni and its contribution to vertical flux in the Southern Ocean. Mar Biol 156: 455-67.

Prusaczyk WK, Stuster JW, Goforth Jr HW, et al. 1995. Physical demands of US Navy Sea-Air-Land (SEAL) operations. San Diego, CA: Naval Health Research Center. Report No. 95-24.

Purcell JE, Uye S, and Lo W-T. 2007. Anthropogenic causes of jellyfish blooms and their direct consequences for humans: a review. Mar Ecol-Prog Ser 350: 153-74.

Purcell JE, Shiganova TA, Decker MB, and Houde ED. 2001. The ctenophore Mnemiopsis in native and exotic habitats: US estuaries versus the Black Sea basin. Hydrobiologia 451: 145-76.

Quiñones J, Monroy A, Acha EM, and Mianzan H. 2013. Jellyfish bycatch diminishes profit in an anchovy fishery off Peru. Fisheries Res 139: 47-50.

Richardson AJ, Bakun A, Hays GC, and Gibbons MJ. 2009. The jellyfish joyride: causes, consequences and management responses to a more gelatinous future. Trends Ecol Evol 24: 312-22.

Robinson KL and Graham WM. 2013. Long-term change in the abundances of northern Gulf of Mexico scyphomedusae Chrysaora sp and Aurelia spp with links to climate variability. Limnol Oceanogr 58: 235-53.

Sarthou GA, Timmermans KR, Blain S, and Tréguer P. 2005. Growth physiology and fate of diatoms in the ocean: a review. $J$ Sea Res 53: 25-42.

Schwartz MW, Bringham CA, Hoeksema JD, et al. 2000. Linking biodiversity to ecosystem function: implications for conservation ecology. Oecologia 122: 297-305.

Sutherland KR, Madin LP, and Stocker R. 2010. Filtration of sub- micrometer particles by pelagic tunicates. P Natl Acad Sci USA 107: 15129-34.

Tacon AGJ and Metian M. 2009. Fishing for feed or fishing for food: increasing global competition for small pelagic forage fish. AMBIO 38: 294-302.

Uye S. 2011. Human forcing of the copepod-fish-jellyfish triangular trophic relationship. Hydrobiologia 666: 71-83.

Vaidya S. 2003. Jellyfish choke Oman desalination plants. http://gulfnews.com/news/gulf/uae/general/jellyfish-chokeoman-desalination-plants-1.355525. 6 May. Viewed 3 Jan 2013.

Vörösmarty CJ, McIntyre PB, Gessner MO, et al. 2010. Global threats to human water security and river biodiversity. Nature 467: 555-61.

Walker B, Holling CS, Carpenter SR, and Kinzig A. 2004. Resilience, adaptability and transformability in social-ecological systems. Ecol Soc 9: 5.

Worm B, Barbier EB, Beaumont N, et al. 2006. Impacts of biodiversity loss on ocean ecosystem services. Science 314: 787-90.

Yu H, Liu X, Xing R, et al. 2006. In vitro determination of antioxidant activity of proteins from jellyfish Rhopilema esculentum. Food Chem 95: 123-30.

${ }^{4}$ The UWA Oceans Institute and School of Plant Biology, The University of Western Australia, Crawley, Australia; ${ }^{5}$ Sea Around Us Project, Fisheries Centre, University of British Columbia, Vancouver, Canada; 'Department of Zoology, University of British Columbia, Vancouver, Canada; ' Shannon Point Marine Center, Anacortes, WA; ${ }^{8}$ Woods Hole Oceanographic Institution, Woods Hole, MA; ${ }^{9}$ Instituto Nacional de Investigación y Desarrollo Pesquero, Mar del Plata, Argentina; ${ }^{10}$ Department of Biology, University of Oregon, Eugene, OR; ${ }^{11}$ Graduate School of Biosphere Sciences, Hiroshima University, Higashi-Hiroshima, Japan; ${ }^{12}$ Australian Rivers Institute and Griffith School of Environment, Griffith University, Gold Coast Campus, Gold Coast, Australia; ${ }^{13}$ National Oceanography Centre, University of Southampton, Southampton, UK; ${ }^{14}$ Dauphin Island Sea Lab, Dauphin Island, AL; ${ }^{15}$ National Oceanic and Atmospheric Administration, National Marine Fisheries Service, Newport, OR; ${ }^{16}$ Department of Biology and Marine Biology, University of North Carolina-Wilmington, Wilmington, NC

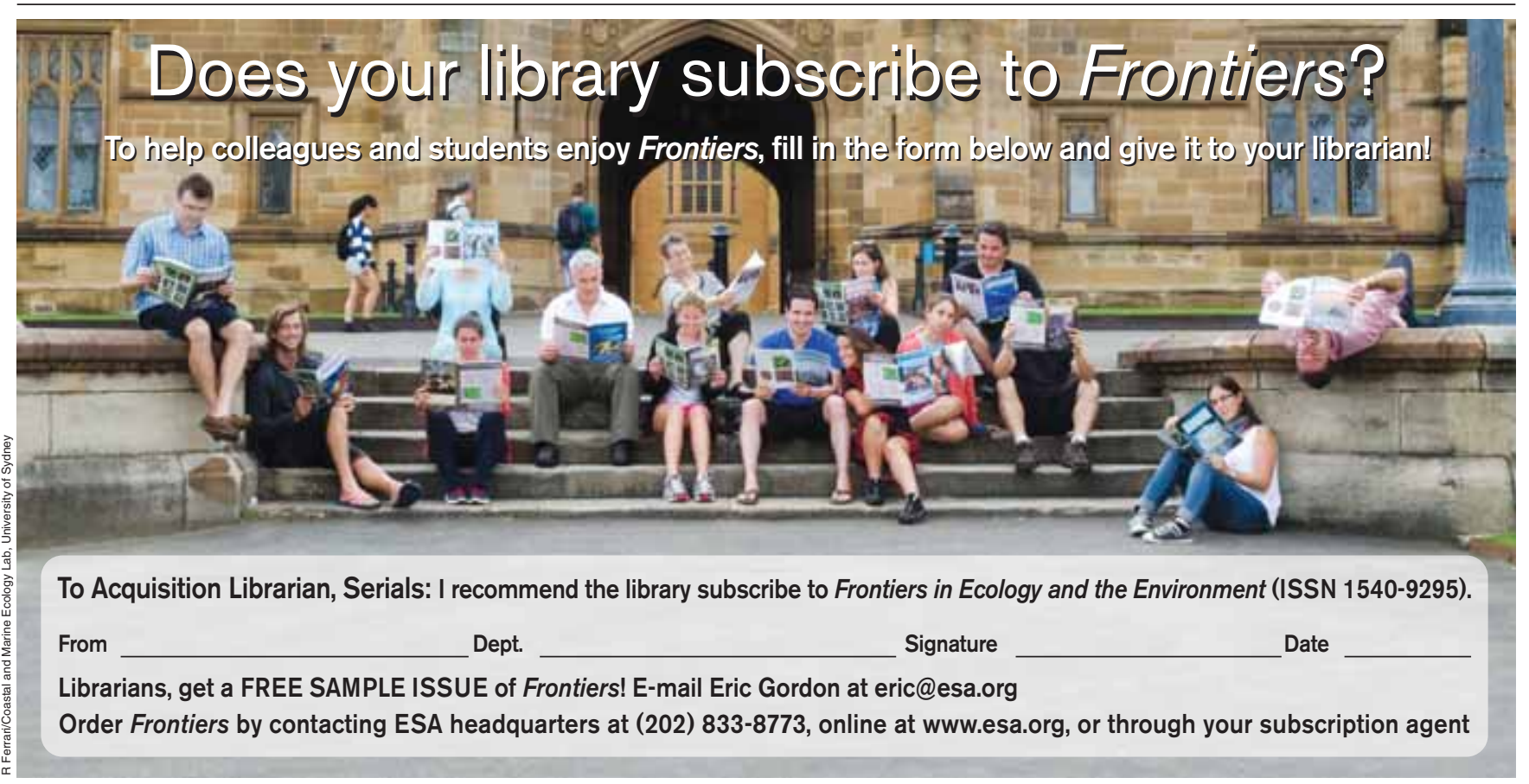

